\title{
Quality Management in Virtual Education
} Management Indicators for Continuous Improvement

\author{
Lucía Melián, Víctor Padrón and Tomás F. Espino \\ UNIVERSITY OF LAS PALMAS DE GRAN CANARIA \\ Imelian@dede.ulpgc.es
}

\begin{abstract}
The important mission of the university institution in society as a body creating and transmitting knowledge justifies higher education being one of the main players in the application of new information and communications technologies (ICTs) in an attempt to exploit the significant advantages that their development can bring to the activity. However, the virtual university faces the challenge of analyzing how the new educational format alters the knowledge learnt in quality management in traditional higher education. New parameters, models and indicators will have to be defined, and new competitive bases will have to be promoted.
\end{abstract}

Key words: Total quality management, virtual higher education, student satisfaction.

\section{INTRODUCTION}

ICTs represent a unique opportunity for the management and creation of knowledge. In effect, the Internet is a super-highway giving access to all types of information, encouraging interactive communications at a world level, reinforcing and boosting understanding, comprehension and knowledge and so contributing to raising world quality at all levels.

From that basic premise, learning has also been subject to this phenomenon. It is obvious that the university, as an institution creating and spreading knowledge, grasps this opportunity to strengthen its role. To that end, it is experiencing and incorporating ICTs, especially the Internet, in its teaching and research work, taking advantage of the flexibility, dynamism and interactivity of the medium to promote communication between educational agents, both inside and outside the institution (Sánchez Allende, García Manso and Díaz Moreno, 2003). 
However, virtual learning in higher education defines a more competitive market since the wider offer contributes to the virtual student being a demanding customer classified as a consumer requiring a university product and service of excellent quality. As a result, this leads to the need to study quality management within virtual universities. The academic literature shows this question (Pond, 2001; Roffe, 2002).

\section{TOTAL QUALITY MANAGEMENT IN THE VIRTUAL UNIVERSITY: A PROGRAM FOR RESEARCH}

Total quality management can be defined as a management philosophy that bases its raison d'être on customer satisfaction as a winning formula to achieve a competitive advantage in the market, involving all the organization and external agents such as suppliers and distributors, among others. The practicality of this model is that it is a multi-company management philosophy; in other words, applicable to any sector, and so, on asking whether TQM has a role to play in virtual university education, the answer is, of course it has.

Firstly, the virtual university is still an institution with a management directed at accomplishing its organizational mission - the creation and transmission of knowledge - which is performed in a digital context with its own characteristics. Secondly, the main client, the student, is more demanding than ever as a result of fierce competition in the market. Consequently, the student takes on a determining role as the key auditor of the academic institution's actions and is demanding not only in terms of quantity but also of quality because of the change in the nature of the service.

With reference to the need and formula for, and the implications of identifying the customer's requirements and demands, a review of the academic and professional literature revealed a series of basic premises. First of all, quality from the customers' perspective is defined as the difference between their expectations and their perceptions of the actions of the company under study. Secondly, quality is a multi-attribute concept; a construct of the second order resulting from the practice of the company in a set of areas of action, dimensions and attributes (Parasuraman, Zeithaml and Berry, 1985, 1988). In this respect, although some authors support the universality of one set of dimensions and attributes for every type of service (Parasuraman, Zeithaml y Berry, 1988), others support scales adapted to the specific context of the study, justified, in part, by the very idiosyncrasy of the field of study (Carman, 1990; Babakus and Boller, 1992). In this respect, 
the differential nature of virtual education indicates the identification of the typical attributes and dimensions (Table 1).

Table 1. Characteristics of the virtual learning environment

\begin{tabular}{ll}
\hline QUALITY & CONCEPT \\
\hline DYNAMIC & Up-to-date knowledge is transmitted in real time. The content and \\
material are subjected to recycling and innovation as changes take \\
place. It is impossible to be in the digital context and not take \\
advantage of the sources of information provided by the Internet to \\
capture and process information relevant to the content of the \\
educational program. \\
Students are in touch with teachers, other students, with the on-line \\
resources of the Internet and with the institution's services. This is \\
possible from the moment that the Net allows the user 24-hour access \\
to the website, promoting interactive communication, which increases \\
the added value of the educational offer. \\
The student perceives a more personalized relationship insofar as there \\
are methods and systems that permit direct, individual dealings with \\
the teaching staff, other students and the institution itself. Moreover, \\
as a result of the interactivity, the institution is on a direct line with \\
each student, gathering information that enables it to identify possible \\
interesting alternatives, adopting and adapting individualized formats. \\
The Internet favors collaboration, the exchange of ideas and \\
discussion by providing the means and the systems, (chats, video- \\
conferences, forums, debates...) to channel them. With collaborative \\
work, the student will acquire skills such as the ability to criticize and \\
work in a team, among others. In this way, constructive knowledge is \\
generated, stemming from sharing it. \\
The student is more active in asking questions and obtaining help in \\
virtual learning. He/she assumes more responsibility for his/her \\
learning by having to seek information, show an initiative to work in a \\
team and identify his/her own resources. The student can decide when \\
and how to progress with his/her educational project, once again \\
revealing the status quo of the Internet user: self-service and self- \\
control.
\end{tabular}

At this point, and based, on the one hand, on the acceptance of customer satisfaction as the reference point for the internal management of the virtual university, and on the other, on the recognition of the properties of on-line education, this work addresses two basic objectives: (1) the theoretical proposal of a scale to measure quality in the university from the student perspective and, (2) the identification of the competitive bases of the internal management of the on-line educational institution that contributes to customer satisfaction.

To that end, it was decided to use a complementary methodology. Firstly, there was a review of the theoretical and practical works on success factors in virtual education in the academic literature and an examination of virtual education websites in order to construct the scale of quality. Secondly, based 
on the gap model of Parasuraman, Zeithaml and Berry (1985), and after a study of the literature related to the resources and capabilities necessary to operationalize a virtual university, the criteria of internal management were linked to the evaluative criteria of the student.

The works reviewed included the contributions of Lieblein (2000), Sánchez Allende, García Manso and Díaz Moreno (2003), Tascón Trujillo (2003), as well as the empirical research of McGorry (2002) and Song et al. (2004).

\section{PARAMETERS OF ACTION IN VIRTUAL HIGHER EDUCTION: AREAS OF ACTION AND COMPETITIVE BASES}

Given the idiosyncrasy of higher education in the digital context, there is an analysis to identify the criteria to evaluate organizational excellence from the student perspective, and the factors of its internal management that contribute to student satisfaction.

\subsection{Attributes and Dimensions of Quality in Virtual Higher Education}

A review of the relevant academic and professional literature and an examination of websites devoted to on-line university education led to the extraction of a model that presents quality as a higher order construct comprising a set of dimensions - institutional quality, functional quality and relational quality - and sub-dimensions with their respective explanatory attributes.

As well as serving as a reference for organizational action, it offers the added value of explaining what each section-dimension and sub-dimensioncontributes to and subsequently attracts the client.

\subsubsection{Institutional quality as the fundamental core}

Institutional quality affects the actions of the on-line educational institution regarding its making its activity known, projecting an image to the market and seeking a competitive position.

It represents the basic management nucleus from which every organizational action materializes since it refers to the disposition to offer determined academic products and services as well as those that are nonacademic but relevant to an educational activity; it materializes in the image and the offer (Table 2). 
Table 2. Institutional quality

\begin{tabular}{|c|c|}
\hline $\begin{array}{l}\text { SUB-DIMENSIONS AND } \\
\text { OBJECTIVES }\end{array}$ & ATTRIBUTES \\
\hline IMAGE & $\begin{array}{l}\text { The student can access the administration and secretariat } \\
\text { services to handle procedures and formalities. }\end{array}$ \\
\hline $\begin{array}{l}\text { Inform the institution's main } \\
\text { client, i.e. the student. }\end{array}$ & $\begin{array}{l}\text { The student has alternative, effective means of access to } \\
\text { the institution's representatives. }\end{array}$ \\
\hline Create a market image. & The institution gives relevant information about the \\
\hline $\begin{array}{l}\text { Transmit security and } \\
\text { responsibility to the student. }\end{array}$ & $\begin{array}{l}\text { organization, such as its history, credentials and activity } \\
\text { performed, resources, study programs, academic and }\end{array}$ \\
\hline $\begin{array}{l}\text { Advertise the academic products } \\
\text { and services. }\end{array}$ & $\begin{array}{l}\text { financial results of previous years, services, and faculty } \\
\text { staff. }\end{array}$ \\
\hline $\begin{array}{l}\text { Convince the student of the } \\
\text { institutional capacity to undertake }\end{array}$ & $\begin{array}{l}\text { The institution takes responsibility for protecting student } \\
\text { data on the Internet and authors' copyrights. }\end{array}$ \\
\hline \multirow[t]{2}{*}{ an e-learning project } & $\begin{array}{l}\text { The institution programs visits to the campus, making } \\
\text { university life more tangible. }\end{array}$ \\
\hline & $\begin{array}{l}\text { The institution has a digital platform that allows it to } \\
\text { perform its administrative, academic and social work in } \\
\text { an optimum manner. }\end{array}$ \\
\hline OFFER & $\begin{array}{l}\text { The educational offer is of social interest, meeting the } \\
\text { needs of the job market. }\end{array}$ \\
\hline $\begin{array}{l}\text { Supply a flexible offer adapted to } \\
\text { the students' limitations }\end{array}$ & $\begin{array}{l}\text { There is a wide range of study plans and vocational } \\
\text { activities. }\end{array}$ \\
\hline regarding time and location. & The student is offered up-to-date, interesting offers such \\
\hline $\begin{array}{l}\text { Deal with the economic, social } \\
\text { and cultural areas demanded by }\end{array}$ & $\begin{array}{l}\text { as: job offers, research groups, masters and specialized } \\
\text { courses. }\end{array}$ \\
\hline $\begin{array}{l}\text { professionals and that arouse } \\
\text { interest in learning. }\end{array}$ & $\begin{array}{l}\text { The student is offered access to, and participation and } \\
\text { collaboration with, other universities. }\end{array}$ \\
\hline $\begin{array}{l}\text { Exploit the resources that other } \\
\text { institutions can provide. }\end{array}$ & $\begin{array}{l}\text { The student is offered access to, and participation and } \\
\text { collaboration with companies and institutions. }\end{array}$ \\
\hline
\end{tabular}

\subsubsection{Functional quality as a means to channel the activity}

Functional quality evaluates the execution of the on-line educational activity; the form and method that brings institutional quality into effect is operationalized. Therefore, in this dimension, we assess the institution's fulfillment of its raison d'être. Three sub-dimensions are used for this: design, material and teaching (Table 3 ).

Table 3. Functional quality

SUB-DIMENSIONS AND ATTRIBUTES
OBJECTIVES

\section{DESIGN}

Guide the student.

Avoid confusion and transmit security.
The website design is attractive, entertaining, thus

encouraging navigation.

Navigation is simple and intuitive.

The operating technique is correct.

The page download is relatively quick. 


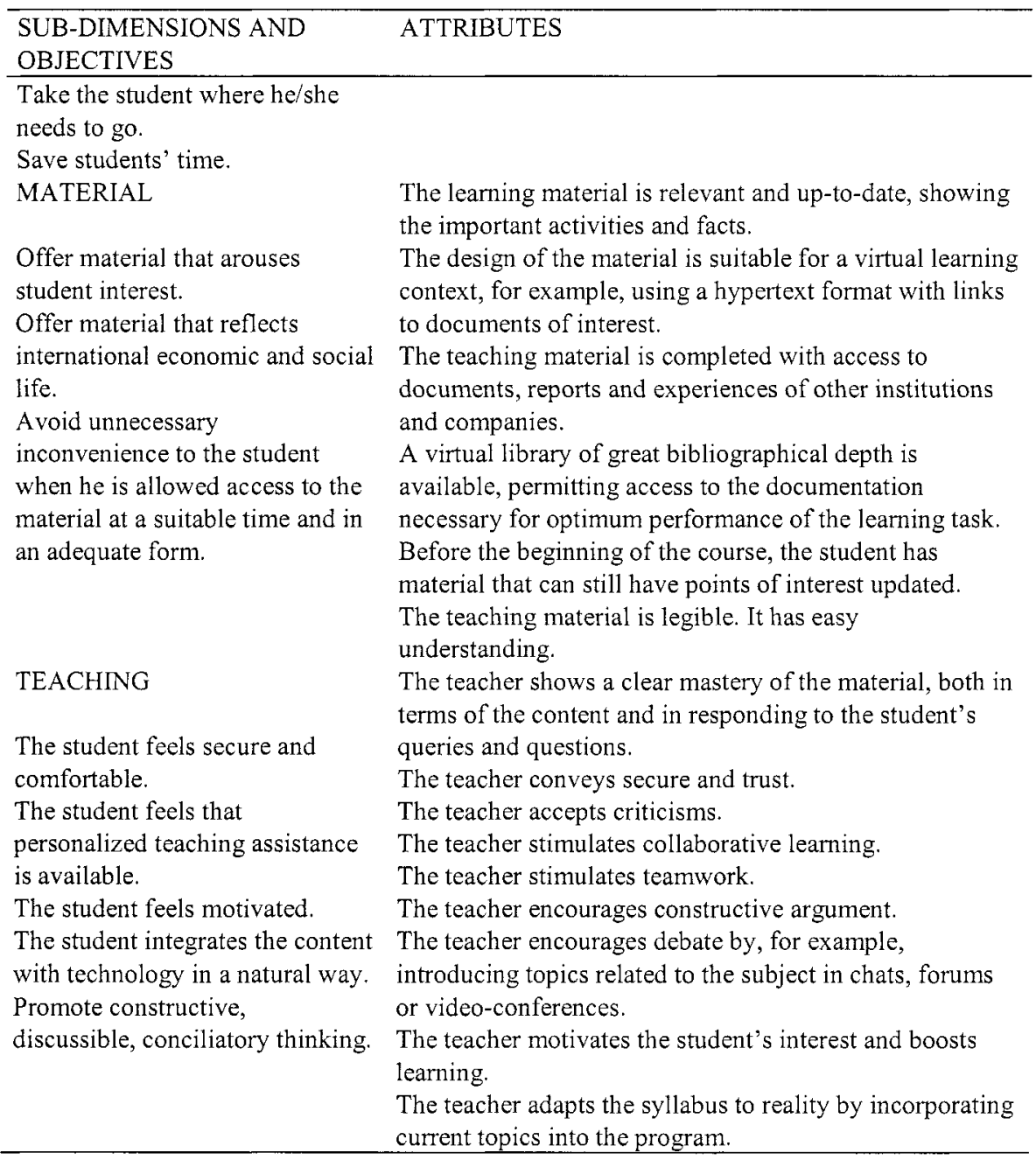

\subsubsection{Relational quality as a vehicle to promote loyalty}

Relational quality is the third level of organizational action to be evaluated. Although it could be included as part of functional quality because it operationalizes university life, its identification has been considered individually for one basic reason: it comprises the essence of the new information and communications technologies, which is personalization and interactivity.

In other words, the personalization and the interactivity are the subdimensions of the relational quality. The personalization adapts the academic offer to individual demands and the interactivity helps to do it. 
The result of this philosophy is an attempt to create a virtual climate that favors the retention of the student as a customer that always finds a learning opportunity in the institution's offer, which is developed through personalization and interactivity (Table 4).

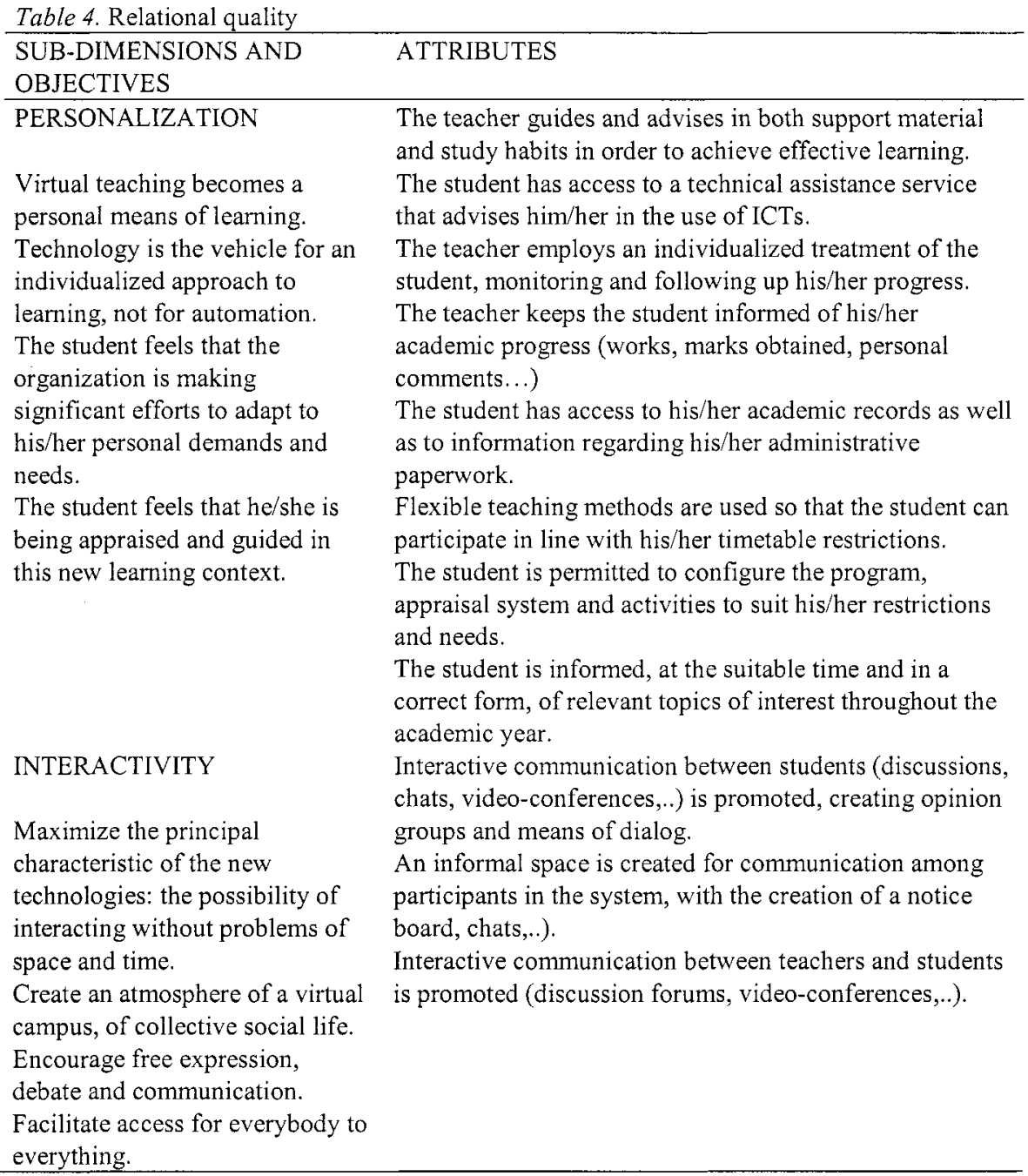

\subsection{COMPETITIVE BASES OF THE VIRTUAL UNIVERSITY FROM THE GAP MODEL}

The Gap model, developed by Parasuraman, Zeithaml and Berry (1985) for physical environments and later modified by Zeithaml, Parasuraman and Malhotra $(2000,2002)$ for virtual environments, defines the quality 
perceived by the user as the result of the size and direction of four organizational discrepancies or gaps associated with information, design, operations and communication: (a) Gap 1, the information gap, is the difference between the users' expectations and the managers' perceptions of the users' expectations (b) Gap 2, the design gap, is the difference between the managers' perceptions of the users' expectations and the specifications of quality established in the design, (c) Gap 3, the operations gap, is the difference between the design specifications and the service actually provided; and, (d) Gap 4, the communication gap, is the difference between the service provided and that which is communicated to the users.

In this way, the quality perceived by the user, also called Gap 5, is the result of the difference between the service provided and the expectations and is the accumulated effect of the four previous gaps. This means that the gap model would combine the following parts in a common framework: (1) evaluation of e-quality and its consequences (the user part) and (2) the organizational deficiencies that could reduce e-quality (the organization part).

Once the customer perspective is analyzed and taking this model as a reference, its use in the case of the virtual university lies in extracting the key aspects in the internal management in order to achieve optimum action in the evaluative criteria that the student takes a reference.

These key aspects give a detailed description of the competitive bases that a virtual university must control (Table 5 ).

Table 5. Competitive bases of virtual university management

\begin{tabular}{l}
\hline CAUSES OF THE GAPS \\
\hline GAP 1 \\
Insufficient market research. \\
Inadequate use of the research. \\
Lack of interaction between \\
managers and users. \\
Inadequate upward vertical \\
communication.
\end{tabular}

STRATEGIES TO NARROW THE GAPS: COMPETITIVE BASES

Study the level of student satisfaction (e-mail surveys, analysis of complaints and suggestions,...).

Study the level of expectations and demands of novel students.

To promote interaction between management and students there must be forms of access (e-mail, telephone, fax,...), as well as virtual encounters via video-conferences.

The institution's top management must increase meetings and communication with teaching and administrative staff to obtain proposals and suggestions.

GAP 2

Deficiencies in the The university management must be trained in quality management.

commitment of the management.

The university management must believe in Total Quality Management.

Perception of non-viability. Absence of objectives or errors in the establishment of requirements or standards.

The university management must know their resources. The university management must value their resources. The university management must pursue and procure resources from others organizations.

The university representatives must define their areas of 


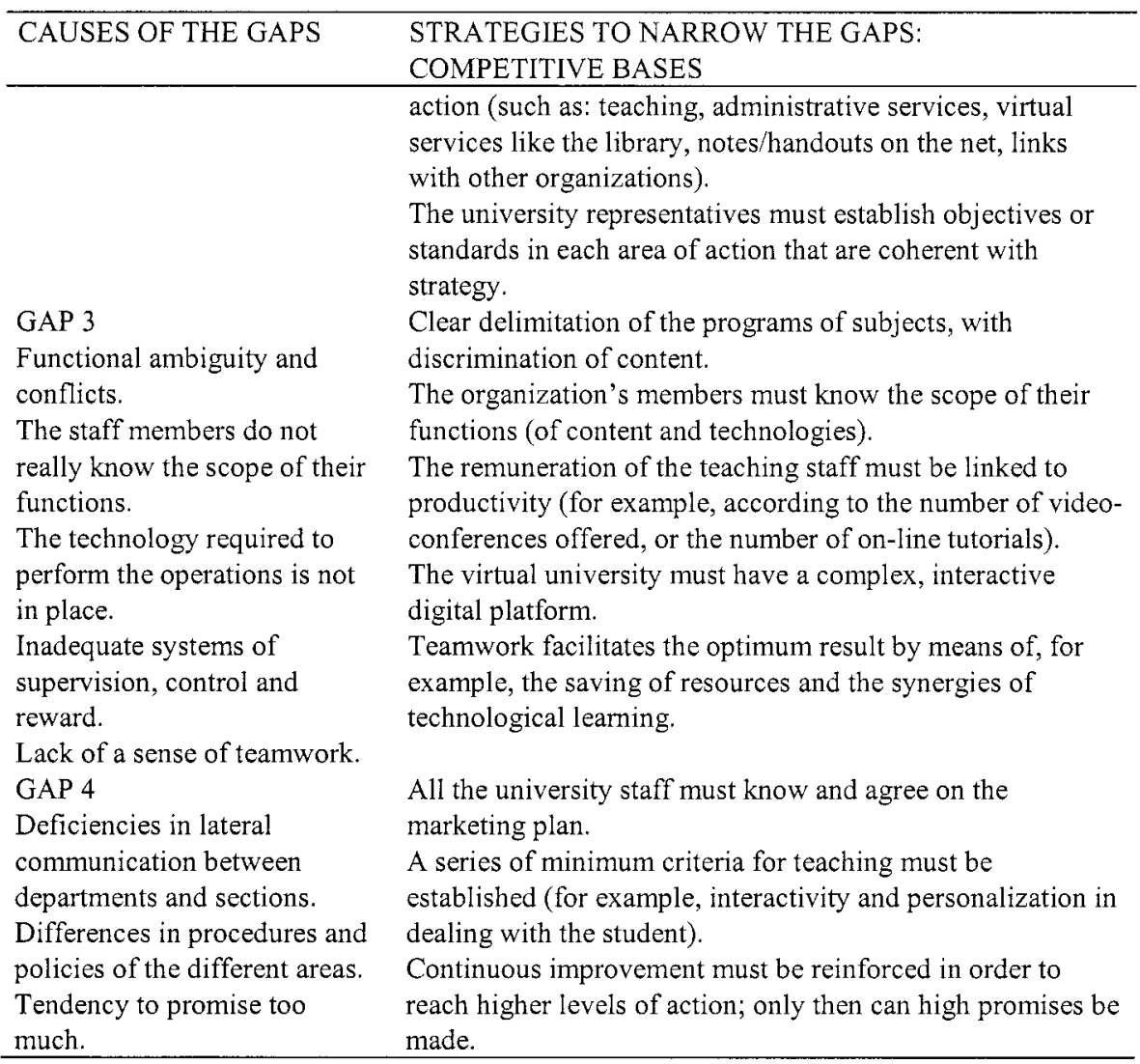

\section{CONCLUSION}

There are two lessons to be learnt by reading this work. Student satisfaction with the virtual university requires optimum action from the institution in three areas: institutional quality (image and offer), functional quality (design, material and teaching) and relational quality (personalization and interactivity). To meet those demands, the university must strengthen a set of competitive bases, including the following: collaboration, training, participation of management, participation of teaching and administration, continuous improvement, information, alliances with strategic partners such as other universities or companies for projects or exchanges. However, the combination of TQM and virtual higher education constitutes an important area of study. In this respect, it is necessary to perform future analyses of aspects such as the application of the EFQM, certification and accreditation subject to the norms, and how strategic alliances contribute to excellence. 


\section{REFERENCES}

Babakus, E. and Boller, G. W. (1992). An empirical assessment of the SERVQUAL scale. Journal of Business Research, 24, 253-268.

Carman, J. (1990). Consumer perceptions of the service quality: an assessment of the SERVQUAL dimensions. Journal of Retailing, 66 (1), 33-55.

Lieblein, E. (2000). Critical factors for successful delivery of online programs. The Internet and Higher Education, 3 (3), 161-174.

McGorry, S. Y. (2003). Measuring quality in online programs. The Internet and Higher Education, 6 (2), 159-177.

Parasuraman, A., Zeithaml, V. A. \& Berry, L. L. (1988). SERVQUAL: a multiple-item scale for measuring consumer perceptions of service quality. Journal of Retailing, 64 (1), 12-40.

Parasuraman, A., Zeithaml, V. A. \& Berry, L. L. (1985). A conceptual model of service quality and its implications for future research. Journal of Marketing, 49, 41-50.

Pond, W. K. (2001). Twenty-first century education and training. Implications for quality assurance. The Internet and Higher Education, 4 (3-4), 185-192.

Roffe, I. (2002). E-lcarning: engagement, enhancement and execution. Quality Assurance in Education, 10 (1), 40-50.

Sánchez Allende, J., García Manso, A. \& Díaz Moreno, P. (2003). Educación virtual: el nuevo apoyo a los estudios universitarios. In L. Joyanes Aguilar \& M. González Rodríguez, (Eds.), II Congreso Internacional de Sociedad de la Información y del Conocimiento, libro de actas (pp.284-289). Spain: McGrawHill.

Song, L., Singleton, E. S., Hill, J. R. \& Koh, M. H. (2004). Improving online learning: student perceptions of useful and challenging characteristics. The Internet and Higher Education, 7 (1), 59-70.

Tascón Trujillo, C. (2003). Aulas virtuales en la Universidad. Nuevos roles y competencias docentes en la teleformación. In L. Joyanes Aguilar \& M. González Rodríguez, (Eds.), II Congreso Internacional de Sociedad de la Información y del Conocimiento, libro de actas (pp.263-270). Spain: McGrawHill.

Zeithaml, V. A., Parasuraman, A. \& Malhotra, A. (2002). Service quality delivery through web sites: a critical review of extant knowledge. Journal of the Academy of Marketing Science, 30 (4), 362-375.

Zeithaml, V.A., Parasuraman, A. \& Malhotra, A. (2000). E-service quality: definition, dimensions and conceptual model. Working paper. Cambridge, MA: Marketing Science Institute. 